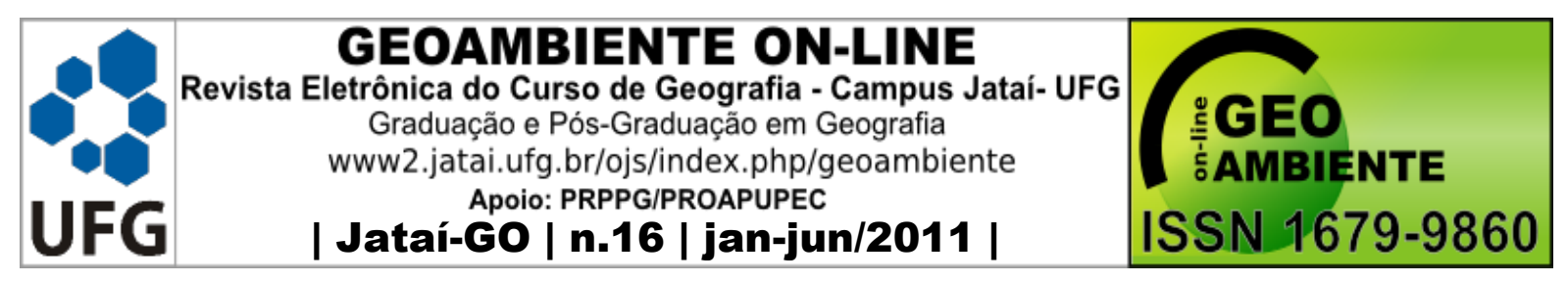

\title{
ELABORAÇÃO DE BASE CARTOGRÁFICA E LEVANTAMENTO GEOAMBIENTAL, COMO SUBSÍDIOS PARA CRIAÇÃO DA UNIDADE DE CONSERVAÇÃO DE USO SUSTENTÁVEL NO MUNICÍPIO DE ARAGOMINAS, NORTE DO TOCANTINS
}

\author{
Benilson Pereira de Sousa ${ }^{1}$ \\ (1 - Universidade Federal do Tocantins, Geógrafo, Bacharel em Geografia pelo Centro \\ Universitário de Brasília - UniCEUB, Licenciado em Geografia pela Universidade Federal do \\ Tocantins - UFT, Graduando em Tecnologia em Gestão Ambiental pela Universidade Norte \\ do Paraná, e pós-graduado lato sensu em Geografia pela Universidade Federal do Tocantins - \\ UFT, email: geofundao@yahoo.com.br)
}

\section{Resumo}

A grande problemática relativa à degradação ambiental provém da falta de práticas conservacionistas e políticas ambientais comprometidas com a realidade local. A presença de recursos ambientais e a necessidade de proteger os ecossistemas locais do impacto das atividades humanas culminaram na proposta de criação de uma Área de Proteção Ambiental (APA) no município de Aragominas, norte do estado do Tocantins. Foi realizada uma caracterização das unidades geoambientais e elaboração das bases cartográficas. Para tal, foi necessária a compreensão do ambiente físico através das relações que se estabelecem entre seus elementos, como: o relevo, geologia, solo, vegetação, em associação com as atividades humanas. A criação da APA Pé do Morro permitirá a conservação de uma porção significativa da biodiversidade local. A fim de, melhorar a qualidade de vida das populações residentes através da orientação e disciplina das atividades econômicas locais e preservação da cultura e tradição da região.

Palavras-chave: Unidade de Conservação, Unidades Geoambientais, Aragominas, APA Pé do Morro

\section{Abstract}

Artigo recebido para publicação em 02 de Dezembro de 2010 Artigo aprovado para publicação em 15 de Maio de 2011 


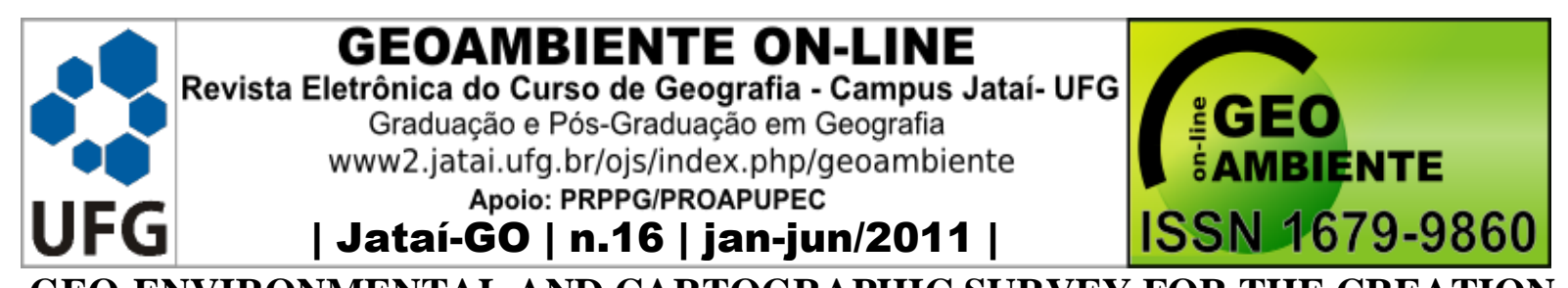

GEO-ENVIRONMENTAL AND CARTOGRAPHIC SURVEY FOR THE CREATION OF CONSERVATION UNITS OF SUSTAINABLE USE IN THE MUNICIPALITY OF ARAGOMINAS, NORTH OF TOCANTINS.

The big issue on the environmental degradation comes from the lack of conservation practices and environmental policies committed to the local reality. The presence of environmental resources and the need to protect local ecosystems from the impact of human activities culminated in the proposal to establish an Environmental Protection Area (APA) in the municipality of Aragominas, northern state of Tocantins. was performed A characterization of the units and compilation of geo-environmental cartographic databases. To this end, it was necessary to understand the physical environment through the relationships established between its elements, such as relief, geology, soil, vegetation, in association with human activities. The creation of the APA Pé do Morro will allow the preservation of a significant portion of local biodiversity. In order to improve the quality of life of local residents through the guidance and discipline of local economic activities and preservation of culture and tradition of the region.

Key words: Conservation Unit, Units Geoenvironmental, Aragominas, APA Pé do Morro.

\section{Resumen}

\section{PREPARACIÓN DE LA BASE DE CARTOGRAFÍA Y COMPLEMENTOS} ENCUESTA GEOAMBIENTAL COMO PARA LA CREACIÓN DE LA UNIDAD DE ALMACENAMIENTO EN EL MUNICIPIO DE USO SOSTENIBLE ARAGOMINAS, AL NORTE DE TOCANTINS.

El gran problema de la degradación del medio ambiente proviene de la falta de prácticas y políticas de conservación ambiental comprometida con la realidad local. La presencia de los recursos ambientales y la necesidad de proteger los ecosistemas locales por el impacto de las actividades humanas culminó con la propuesta de crear un Área de Protección Ambiental (APA) en el municipio de Aragominas, norteño estado de Tocantins. Una caracterización de las unidades y la compilación de bases de datos cartográficas geo-ambientales. Para ello, era necesario comprender el entorno físico a través de las relaciones establecidas entre sus elementos, tales como el alivio, la geología, suelos, vegetación, en asociación con las actividades humanas. La creación de la APA Pé do Morro, se permitirá la preservación de una parte significativa de la biodiversidad local. Con el fin de mejorar la calidad de vida de los 


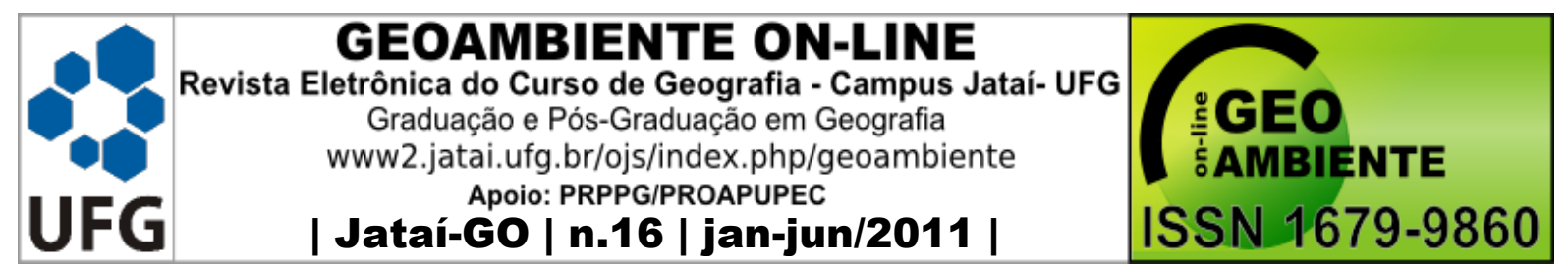

residentes locales a través de la orientación y disciplina de las actividades económicas locales y la preservación de la cultura y la tradición de la región.

Palabras clave: Unidades de Conservación, unidades de base geoambiental, Aragominas, APA Pé do Morro.

\section{Introdução}

A presença de recursos ambientais e a necessidade de proteger os ecossistemas locais do impacto das atividades humanas culminaram na proposta de criação de uma Área de Proteção Ambiental (APA) no município de Aragominas, norte do estado do Tocantins. Utilizando técnicas de geoprocessamento e sensoriamento remoto, a proposta é embasada numa série de estudos sobre os principais aspectos físicos, bióticos e antrópicos da região, com vistas a gerar subsídios para a proposta de criação da APA Pé do Morro.

A partir das dinâmicas espaciais existentes na área, tem-se como objetivo principal a delimitação de área para a criação de Unidade de Conservação no município Aragominas-TO, embasando-se em técnicas cartográficas. Foi elaborado um banco informações geoambientais e de documentação cartográfica, que possibilite estudos e o desenvolvimento de práticas conservacionistas na área, disponibilizando-o em formato analógico e digital.

Esta iniciativa tem como objetivo promover uma integração harmoniosa entre as atividades produtivas da região e a conservação da natureza, buscando o uso sustentável dos recursos naturais e melhores condições de vida para a população local.

Estas informações estabeleceram os fundamentos para a futura gestão ambiental e regulamentação da APA, direcionando os programas de desenvolvimento sustentável e a elaboração do zoneamento ecológico-econômico completo, posterior a sua criação.

A consolidação de uma APA somente é efetivada de fato, através de estudos elaborados por Zoneamento Ecológico-Econômico e de um Plano de Gestão, instrumento de planejamento oficial das APA's. O Plano de Gestão consiste em um documento elaborado com a participação das instituições públicas e privadas, e com a participação de organizações comunitárias envolvidas e interessadas com a criação da área. Apoiado em princípios de gestão estabelecidos de acordo aos objetivos da APA, apresenta diretrizes e estratégias voltadas ao manejo dos recursos naturais conciliado às atividades humanas ali desenvolvidas.

\section{2 Áreas de Proteção Ambiental}




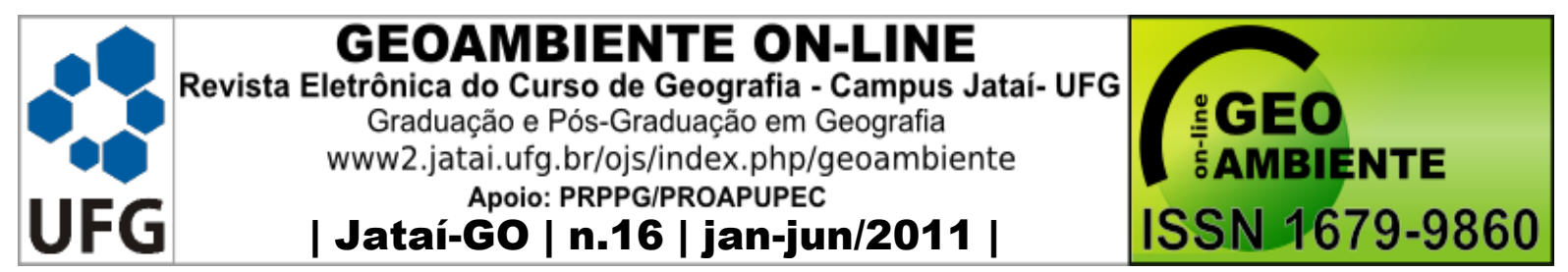

Com o advento do Sistema Nacional de Unidades de Conservação (SNUC), através da Lei $\mathrm{n}^{\circ} 9.985$ de 18 de julho de 2000, houve um grande avanço no que se refere a proteção e o uso sustentável dos recursos naturais.

No Artigo $2^{\circ}$ da Lei $n^{\circ} 9.985 / 2000$, institui Unidade de Conservação como espaço territorial e seus recursos ambientais, incluindo as águas jurisdicionais, com características naturais relevantes, legalmente instituído pelo Poder Público, com objetivos de conservação e limites definidos, sob regime especial de administração, ao qual se aplicam garantias adequadas de proteção (BRASIL, 2000).

A citada lei enquadra as unidades de conservação, em duas categorias: as de Proteção Integral e as de Uso Sustentável (tabela 1).

Tabela 1 - Grupos e Categorias de Unidades de Conservação de acordo o SNUC.

\begin{tabular}{l|l}
\hline Unidades de Proteção Integral & Unidades de Uso Sustentável \\
\hline Estação Ecológica & Área de Proteção Ambiental \\
Reserva Biológica & Área de Relevante Interesse Ecológico \\
Parque Nacional & Floresta Nacional \\
Monumento Natural & Reserva Extrativista \\
Refúgio de Vida Silvestre & Reserva de Fauna \\
Parque Estadual & Reserva de Desenvolvimento Sustentável \\
Parque Natural Municipal & Reserva Particular do Patrimônio Natural \\
\hline
\end{tabular}

Segunda a Lei n ${ }^{0}$ 9.985/2000, a Área de Proteção Ambiental (APA) é uma categoria de Unidade de Conservação, voltada para a proteção de riquezas naturais que estejam inseridas dentro de um contexto de ocupação humana. O principal objetivo é a manutenção da diversidade biológica, a conservação de sítios de beleza cênica e a utilização racional dos recursos naturais (BRASIL, 2000).

A Resolução CONAMA 10/1988 artigo $1^{\circ}$, assim define: APA's, "unidades de conservação destinadas a proteger e conservar a qualidade ambiental e os sistemas naturais, visando à melhoria da qualidade de vida da população local e também a proteção dos ecossistemas regionais" (CONAMA, 1988).

As Unidades de Conservação gerenciam por meios de manejos adequados a pressão que as diversas atividades econômicas geram sobre a biodiversidade. CABRAL (2002, p. 22) cita que, "frente a este conflito, são necessárias medidas que garantam a perenidade dos recursos naturais, a fim de assegurar boas condições de vida para a presente e as futuras 


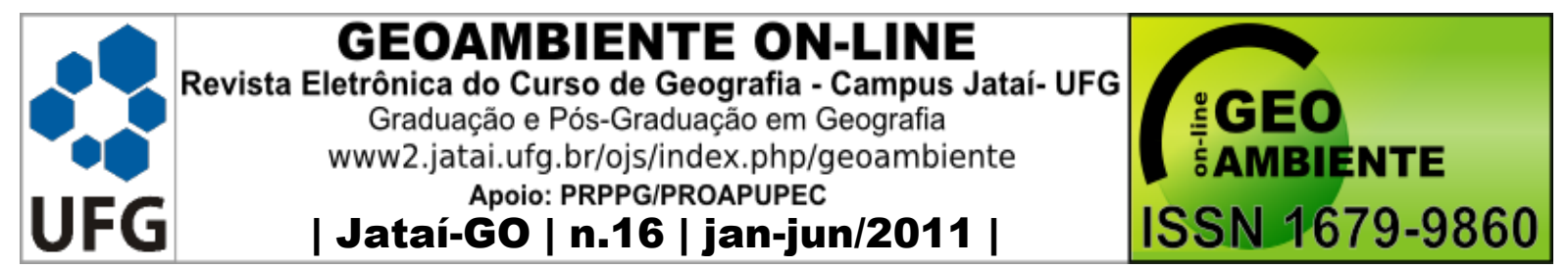

gerações”. Nesse contexto, as Unidades de Conservação (UC's) são mecanismos adequados de preservação dos recursos ambientais.

Segundo PERINOTTO (2007) as APA's têm como características marcantes a possibilidade de manutenção da propriedade privada e do estilo de vida tradicional da região, onde programas de proteção à vida silvestre podem ser implantados, sem que haja necessidade de desapropriação de terras. Desta forma, essa metodologia de ação é apropriada para a região de Aragominas, uma vez que a falta de recursos financeiros para a desapropriação de terras limita a implantação e consolidação de outros programas de conservação e uso sustentável dos recursos naturais.

O processo de implantação de uma APA envolve diversas etapas e procedimentos legais e técnicos. Sua simples criação, através de instrumento legal (lei, decreto, resolução ou portaria), constitui apenas o primeiro passo, que deve ser seguido pela regulamentação destas leis e decretos e pela a implantação de um complexo sistema de gestão ambiental (PARANÁ ${ }^{1}$, citado por TAMANINI, 2008, p.10). Assim, devem ser definidos criteriosamente os instrumentos gerenciais, como o zoneamento ambiental, o plano de gestão e os instrumentos fiscais e financeiros para garantir o cumprimento dos objetivos básicos da APA.

No Estado do Tocantins já foram criadas 13 APA's entre federais, estaduais e municipais atingindo vários municípios e protegendo uma grande variedade de paisagens e ecossistemas, numa extensão superior a 2.900 .000 hectares (TOCANTINS - NATURATINS, 2008).

\section{Material e Métodos}

Através do levantamento e análise da bibliografia montou-se um acervo sobre as unidades geoambientais e aspectos antrópicos, de tal modo que foi possível alcançar um conhecimento sobre a área de estudo e efetuar uma análise prévia da viabilidade desta proposta. Como trata DIAS (2007), faz-se necessário a compreensão do ambiente físico através das relações que se estabelecem entre seus elementos apontados neste trabalho como o relevo, geologia, solo, vegetação em associação com as atividades humanas.

A próxima etapa foi à manipulação e o cruzamento das informações digitais provenientes do banco de dados geográfico SIG/GEO-TOCANTINS (SEPLAN, 2002), contendo os níveis de informações como: limites municipais, bacias hidrográficas, hidrografia, sede dos municípios, uso e cobertura, estradas e vulnerabilidade. Para fomentar as 


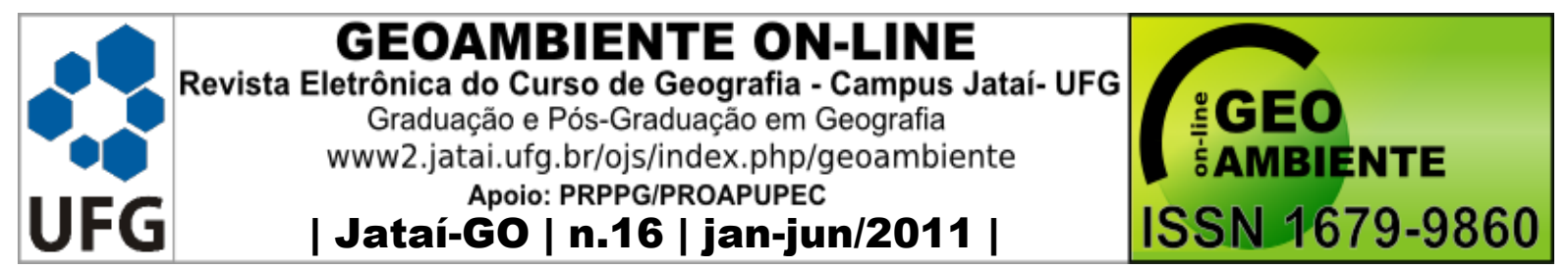

análises, o banco de dados foi realimentado com informações espaciais recentes, no que tange ao uso e cobertura atual.

O banco de dados disponível foi elaborado em escala de 1:100.000 (SEPLAN, 2002). As cartas que foram produzidas, por se tratar de uma área relativamente pequena, foram elaboradas na escala 1:50.000, escala de semi-detalhe. A base de 1:100.000 não é um fator limitante para a manipulação e as tabulação dos dados, apenas requer uma análise mais criteriosa e trabalho a campo mais preciso e abrangente.

Com base no banco de dados e apoiado em técnica de observação direta em campo, elaborou-se mapas com vários planos de informação, tais como: Limites sugerido para a APA,

1 PARANÁ, Governo do Estado do: APA Estadual do Passaúna: Zoneamento Ecológico-Econômico Curitiba, 1995, 192 p. Convênio: "Programa Impactos Ambientais de Barragens" - PIAB, Coordenação da Região Metropolitana de Curitiba - COMEC, Deutsche Gesellschaft Fui Technische Zusammenarbeit - GTZ e Instituto. Vulnerabilidade, Hidrográfico, Bacias Hidrográficas, Uso e Cobertura Vegetal, e Modelo Digital de Elevação (MDE). Utilizando dos softwares ArcGis 9.2 (ESRI@,2006) e GPS TrackMaker Pro®.

O processo de Modelagem Digital de Elevação (MDE) é uma estrutura numérica de dados que representa a distribuição espacial de uma variável quantitativa e contínua (PÉREZ, 1992). Sua elaboração se deu a partir de dados de Radar, utilizando imagem SRTM (Shuttle Radar Topography Mission), a qual subsidiou a compartimentação de relevo e analise da dinâmica geomorfológica da área.

O sistema de projeção adotado como padrão para todos os níveis de informações geradas, foi o denominado UTM (Universal Transverse Mercator), datum SAD 69 (South American Datum) e zona 22S. Sendo o mesmo utilizado no banco de dados SIG/GEOTOCANTINS (SEPLAN, 2002).

Foram utilizadas imagens georreferenciadas dos sensores Landsat TM5, anos de passagem 2002, 2004, 2008 e 2009 e CBERS (China-Brazil Earth-Resources Satellite) 2006, referentes à órbita/ponto 223-65 e cena 160/108 respectivamente. As imagens são oriundas dos bancos de imagens SISCOM adquiridas na internet, disponível no Sistema Compartilhado de Informações Ambientais do IBAMA (Instituto Brasileiro do Meio Ambiente e dos Recursos Naturais Renováveis) e do NATURATINS (Instituto Natureza do Tocantins).

O uso de imagens de satélites possibilitou a análise da dinâmica de uso e ocupação da área para posterior atualização do banco de dados de uso e cobertura existente.

Os estudos dos aspectos geoambientais envolveram as seguintes etapas: 


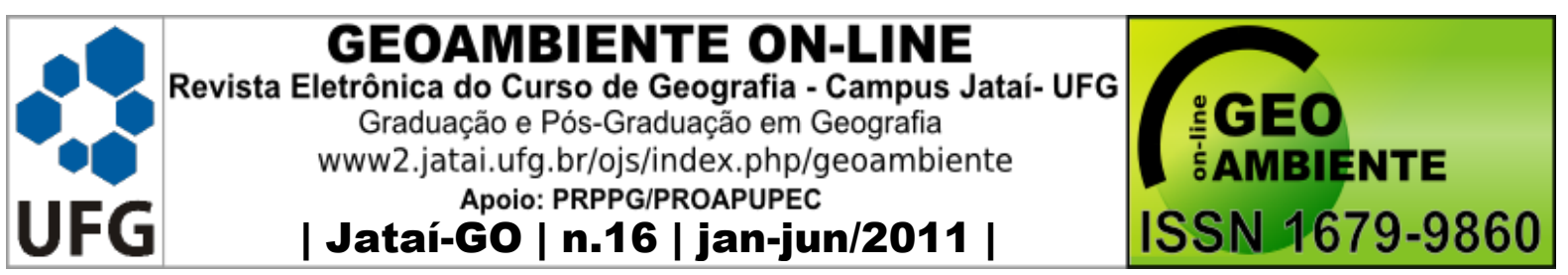

- Identificação espacial dos remanescentes de vegetação natural e classificação prévia das formações vegetais a partir da interpretação digital de imagem de satélite e bando de dados de uso e cobertura do SIG/GEO-TOCANTINS (TOCANTINS-SEPLAN, 2002);

- Conferência em campo das classes de vegetação, com descrição mais detalhada das diversas formações vegetais e fisionomias;

- Caracterização dos tipos de solos, das formações geológicas e feições Geomorfológicas in loco;

\section{Caracterização do Município de Aragominas.}

O município de Aragominas localiza-se na mesorregião ocidental do Estado do Tocantins na microrregião administrativa de Araguaína (07 09' 35"S e 48 31' 39"W), a 345 metros de altitude. Segundo IBGE (2007) sua população é de 5.469 habitantes, sendo que a maior parte concentra-se na zona rural e possui uma área de $1.193 \mathrm{~km}^{2}$ (figura 1).

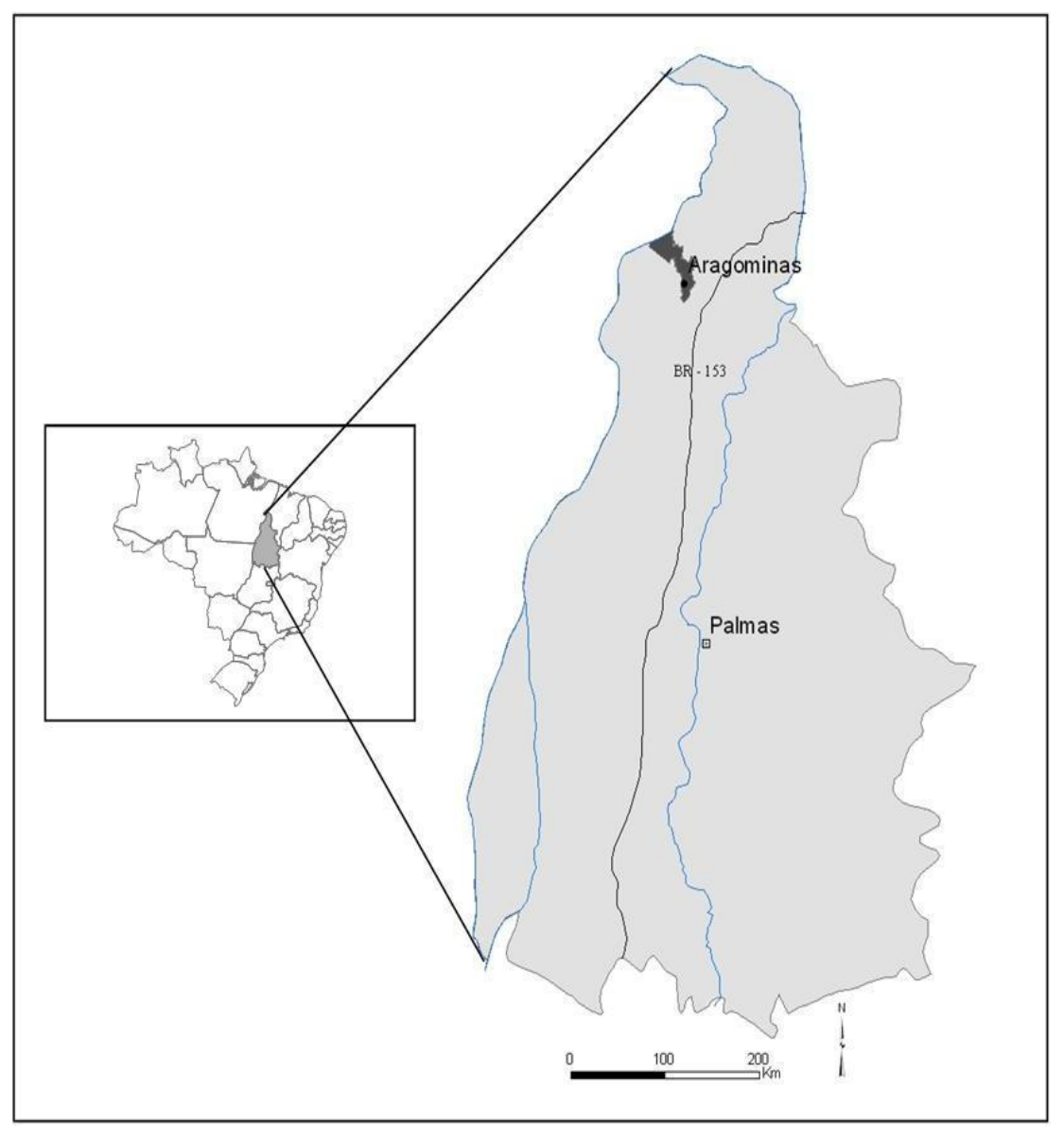

Figura 1 - Localização do Município de Aragominas no estado do Tocantins. 


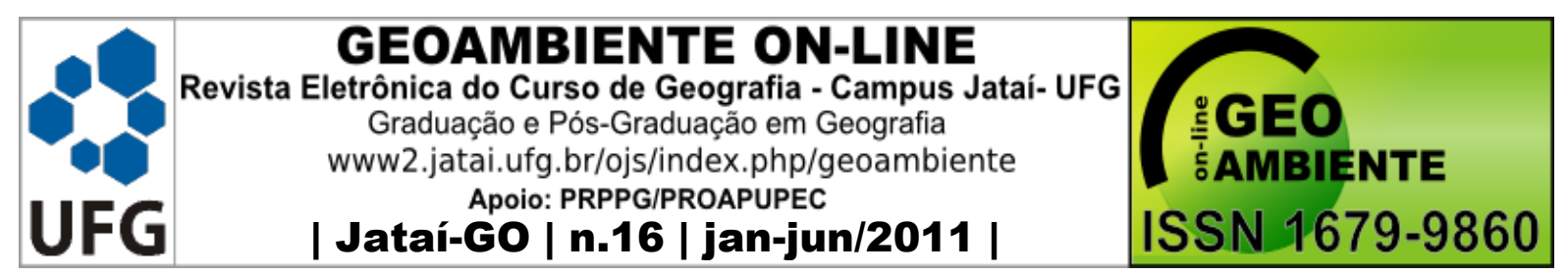

O município de Aragominas é considerado um dos mais valorizados e produtivos da região norte do Estado do Tocantins. Bastante valorizado no que se refere à produção agropecuária. A região onde está inserido a APA Pé do Morro por sua vez, é parte do território onde há uma grande valoração e produção. A base da economia municipal é a agropecuária, tendo como atividades de maior destaque a pecuária intensiva e extensiva e a cultura de cana de açúcar para produção de ração para o gado (BRITO, 2006). O setor secundário não tem contribuição significativa para a geração de renda do município e é composto por algumas indústrias de extração mineral. $\mathrm{O}$ setor terciário caracteriza-se por micro e pequena empresa de administração familiar.

\section{APA Pé do Morro}

A área sugerida para a APA Pé do Morro totaliza 3.399 hectares, o que corresponde a 2,8\% do território municipal. Os seus limites foram traçados em função do limite territorial com o município de Muricilândia, através do Córrego Travessão, seguindo a base da escarpa contornando-a, passando pelo Córrego do Mineiro, incluindo assim, parte da rodovia TO-222 (Figura 2).

A referida área apresentada para compor a APA atinge apenas a área rural, sendo limítrofe a zona urbana. No entanto, alguns programas específicos de gestão ambiental deverão ser trabalhados na área urbana e os benefícios ambientais trazidos pela implantação da APA devem atingir não somente a população rural residente no seu território, mas também a população urbana.

A constituição geomorfológica da área favoreceu a formação de sítios de grande beleza cênica, com a presença de vales e cachoeiras, potencializando alguns destes locais para o desenvolvimento de atividades turísticas e recreativas (figuras 3 e 4). Nestas áreas encontram-se também zonas de mananciais e refúgio de animais silvestres. 


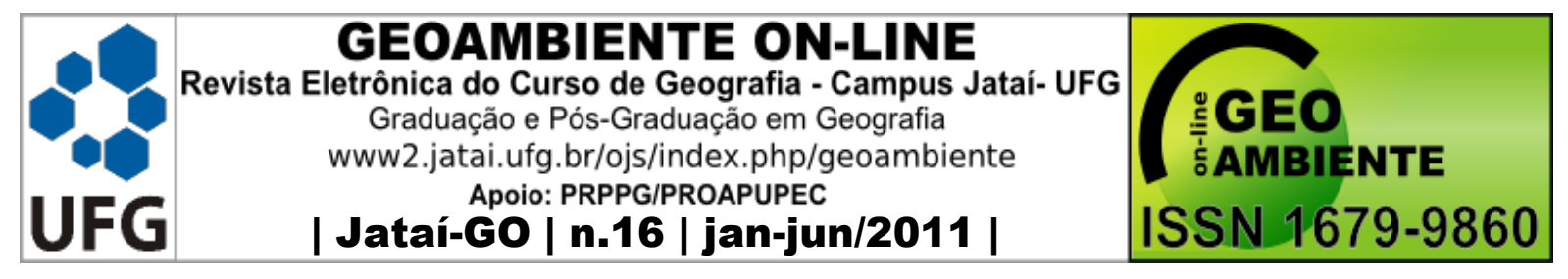

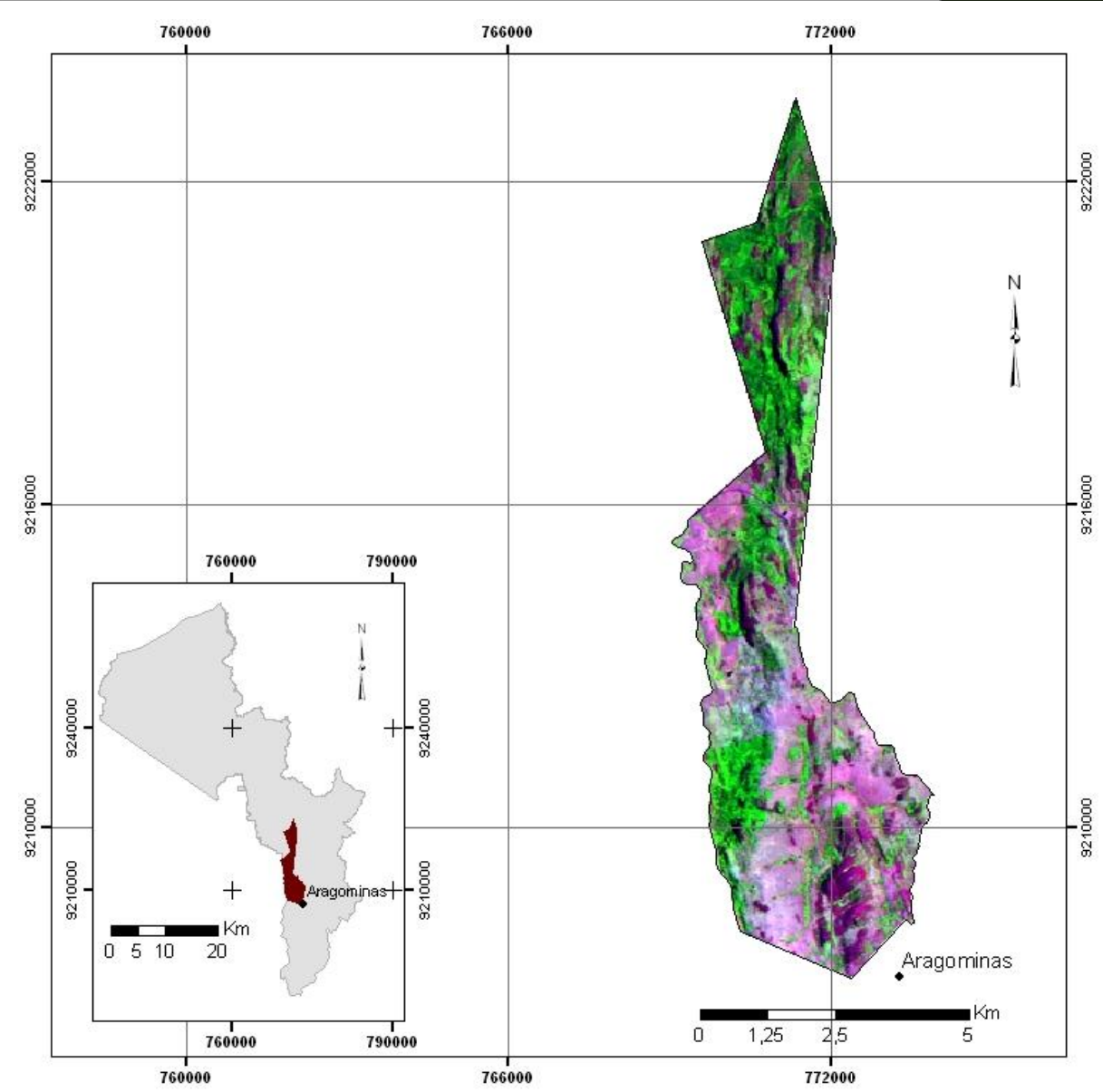

Figura 2 - Mapa de localização da APA no Município de Aragominas.

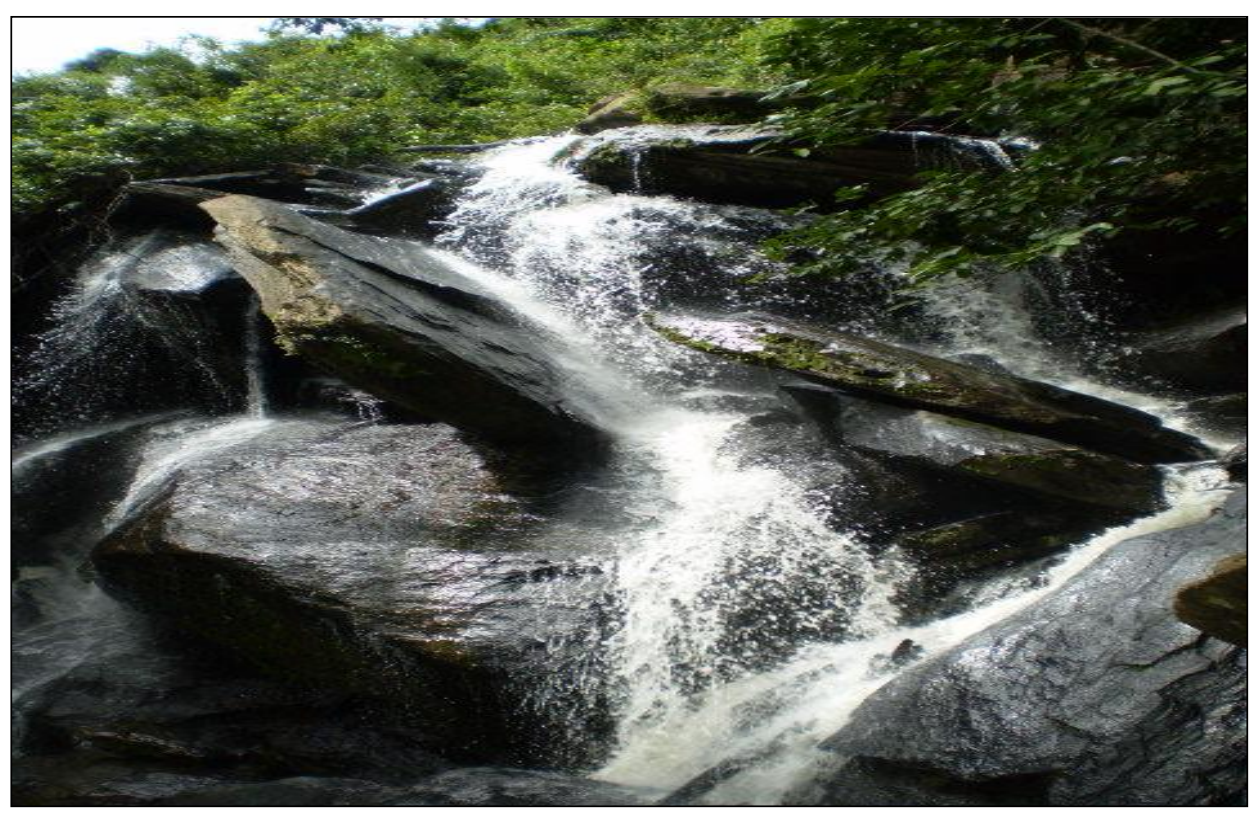

Figura 3 - Cachoeira no interior da APA. 


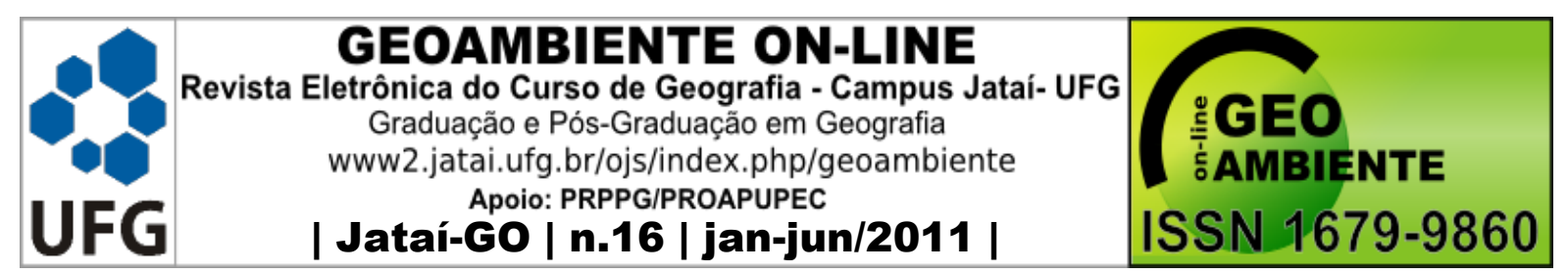

As prioridades estabelecidas em termos de conservação ambiental para a APA Pé do Morro são:

- As áreas de vegetação remanescente que abrigam espécies animais raras na região, com registros de ocorrência de onça pintada (Panthera onca), anta (Tapirus terrestris), urubu-rei (Sarcorhamphus papa), veado mateiro (Mazama americana), entre outros (ZEE-BICO, 2005);

- Os locais de nidificação de aves (ZEE-BICO, 2005);

- Locais com expressiva beleza cênica e potencial turístico;

- As áreas de encostas, que além da beleza cênica e presença de florestas, apresentam grande fragilidade diante da antropização e dos processos erosivos;

- As áreas ligadas à manutenção da qualidade dos recursos hídricos, como áreas de várzeas e margens de rios, e as zonas de mananciais.

No interior da APA tem-se uma considerável quantidade de estradas vicinais, as quais facilitariam o manejo da Unidade de Conservação dando suporte à fisscalização, ao monitoramento e logística para uma eventual brigada de incêndios, pois queimadas são freqüentes na região. $\mathrm{O}$ estado de conservação das estradas vicinais é considerado bom em todas as estações do ano.

No que se refere à criação da APA, a população local foi questionada através de conversas informais, sobre a importância de se preservar a área e criar instrumentos legais para tal. Por unanimidade, a população demonstrou-se interessada na idéia e esperançosos, pois várias vezes foram externados o medo de que grandes empreendimentos de atividade mineradora possam se instalar e causar danos aos morros, fato este evidenciando ainda mais o apego da população com a paisagem do local.

Existe por parte do poder público municipal, uma demanda pela criação da Unidade de Conservação. Fato que esbarra na falta de recursos para contratação de consultoria para elaboração dos estudos técnicos.

\subsection{Aspectos Geoambientais}

A unidade estudada está inserida na faixa de clima segundo a classificação de Thornthwaite, B1wA'a'. Definido por ATLAS DO TOCANTINS (2005) apresentando clima úmido com moderada deficiência hídrica no inverno, evapotranspiração potencial 


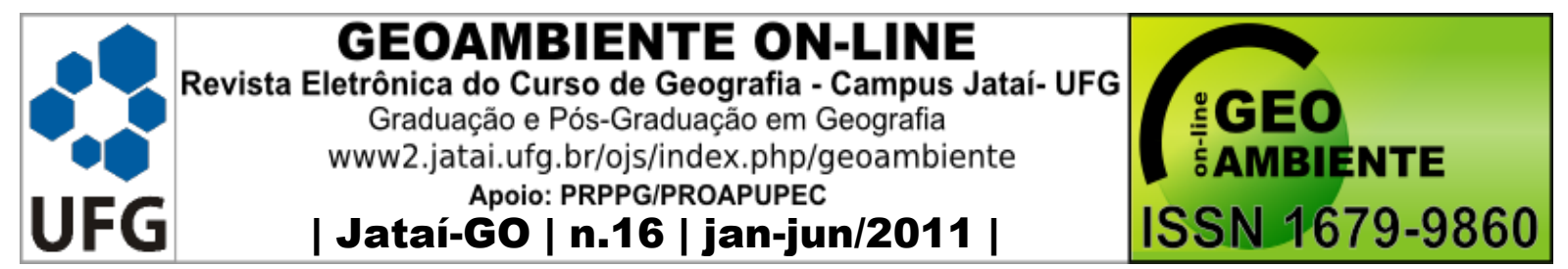

apresentando uma variação média anual entre 1.400 e $1.700 \mathrm{~mm}$, distribuindo-se no verão em torno de 390 e $480 \mathrm{~mm}$ ao longo dos três meses consecutivos.

O clima é caracterizado por apresentar duas estações bem definidas: uma com período chuvoso (novembro a maio) e outra seca (junho a outubro), com médias oscilando entre 1.500 e $1.800 \mathrm{~mm}$ anuais. Nos meses mais secos, as temperaturas médias mensais situam-se acima de $18^{\circ} \mathrm{C}$ e nos meses mais quentes elas são superiores a $25^{\circ} \mathrm{C}$.

Do ponto de vista geológico, a área de abrangência da APA Pé do Morro está inserida na faixa de dobramentos de Proterozóico Médio e Superior. Segundo CPRM (2001), litologicamente faz parte da Formação Xambioá, composto por Muscovita-Biotita-quartzoxistos e calci-biotita-quartzo-xistos, feldspáticos, localmente granatíferos e grafitosos, com lentes de anfibolitos.

Geomorfologicamente está inserida no Planalto Residual do Araguaia. A denominação planalto residual deve-se ao fato da referida Unidade ser constituída por blocos soerguidos residuais, decorrentes de processos de recuo paralelo das vertentes. O contato dessa Unidade com a Depressão do Araguaia se faz através da pronunciada escarpa de falha. Com relação às características da Unidade.

Pode ser observada a Leste da cidade de Muricilândia, com cotas altimétricas que variam de 350 a $500 \mathrm{~m}$, ocorrendo de forma alongada, também acompanhando o sentido N-S. O relevo foi elaborado sobre litologias proterozóicas da Formação Xambioá (muscovitabiotita-quartzo-xisto e calci-biotita-quartzoxisto, com lentes de anfibolitos) e apresenta-se dissecado em formas aguçadas, entre as quais sobressaem-se inúmeras cristas de direção aproximada N-S, acompanhando os lineamentos estruturais e fraturas. Entre Muricilândia e Aragominas observam-se com freqüência escarpas de falhas do gráben do Muricizal destacando-se as formas aguçadas resultantes, topograficamente elevadas em relação à Depressão do Araguaia. Registram-se ainda nesta Unidade afloramentos de xistos sobre outeiros, relacionados à Formação Xambioá. (ZEE-BICO, 2004, p. 13).

O ZEE-BICO (2004) sita que, as estruturas proterozóicas possuem elevado índice de vulnerabilidade, mesmo contando com a resistência litológica dos quartzitos associados aos xistos da formação Xambioá. Ainda segundo ZEE-BICO (2004) nessa morfologia, caracterizada como altamente vulnerável deve-se evitar o desmatamento das áreas mais inclinadas, bem como fazer uso de práticas de conservação do solo quando da implantação de atividades econômicas (figura 6). 


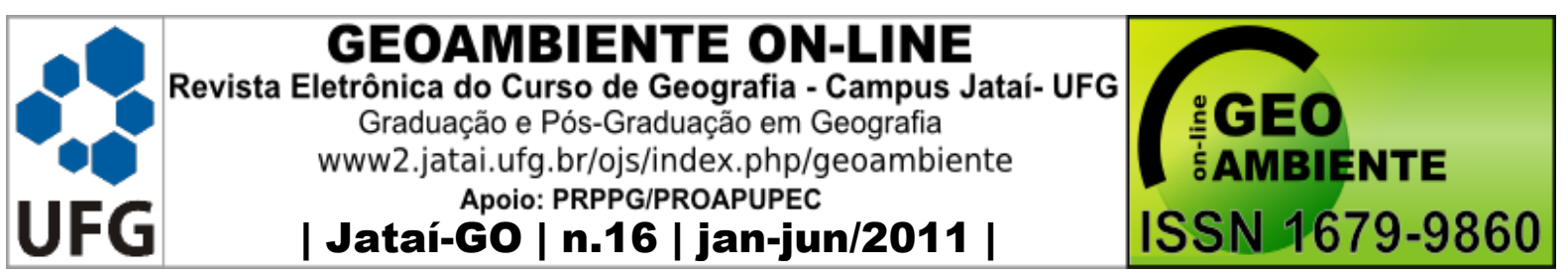

Quanto aos processos erosivos, o que mais se observa no local é a erosão hídrica laminar e ravinar. Processos de grande porte como vossorocas inexistem devido aos solos rasos e afloramentos rochosos. Quanto à topografia, as características dos solos e a cobertura vegetal, proporcionam o escoamento superficial das águas, distribuindo-as pelas encostas de forma dispersa ou em fluxo turbulentos. O grande causador desse processo é o desmatamento na abertura de novas áreas para pastagens e a retirada das áreas de proteção permanentes ao longo das encostas e margens dos corpos hídricos.

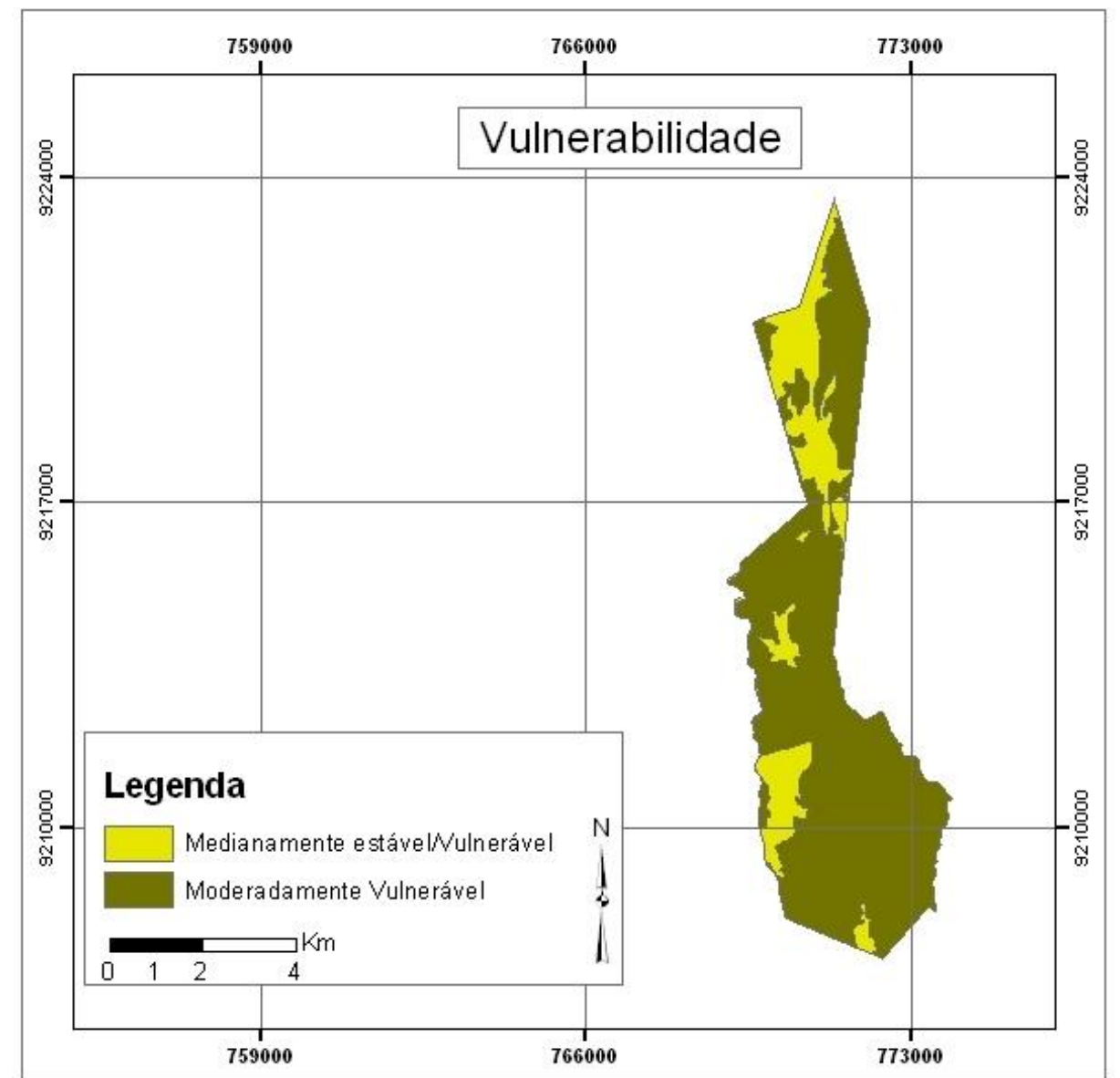

Figura 6- Mapa de Vulnerabilidade da APA Pé do Morro.

Fonte: banco de dados GEO-TOCANTINS/SEPLAN.

Fonte: banco de dados GEO-TOCANTINS/SEPLAN. Elaborado por SOUSA, Benilson P.

Como conseqüência da retirada da vegetação nativa e dos processos erosivos, os corpos hídricos apresentam estágios iniciais de assoreamento, como é o caso do Córrego Travessão. 


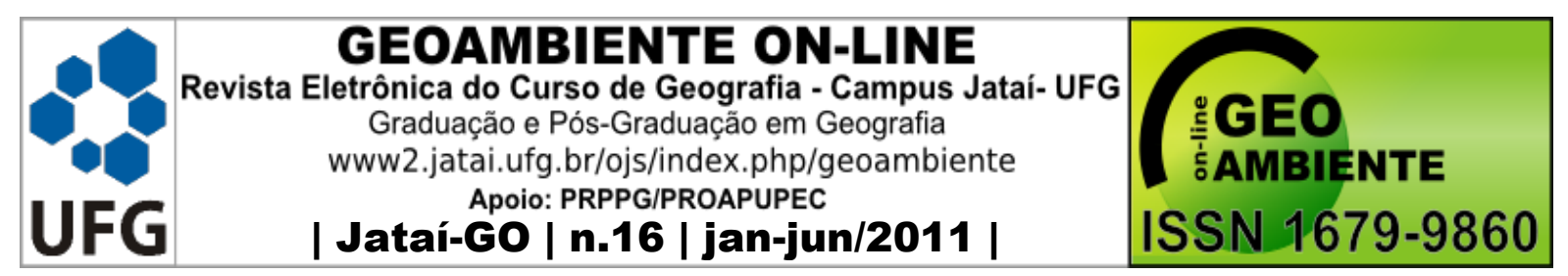

Os tipos de solos encontrados na APA Pé do Morro compõem-se de uma Associação de Solo Litólicos Álico e Distrófico a moderado, textura média, mais Podzólico VermelhoAmarelo Pedregoso Distrófico e Álico a moderado, textura arenosa/média. Solos Litólicos são solos minerais, não hidromórficos, pouco evoluídos e rasos, com horizonte A assente diretamente sobre a rocha ou, em alguns casos, sobre horizonte $\mathrm{C}$ pouco espesso. Sua textura está intimamente relacionada com seu material de origem, ocorrendo solos com textura arenosa, ou média ou argilosa. Os Podzólicos Vermelho-Amarelo são solos minerais, não hidromórficos, moderadamente drenados a bem drenados. Ocorrem em vários tipos de relevos e com diferentes classes texturais como arenosa/média, média e média/argilosa. $\mathrm{Na}$ área da APA foram diferenciadas quatro classes de vegetação e três de uso do solo (ZEE-BICO, 2005).

As atividades desenvolvidas na área são a pecuária intensiva e semi-intensiva, onde a vegetação natural foi substituída por pastagens cultivadas (andropógon, braquiarão e quicuio) que estão em diferentes estágios de conservação (limpa, suja e encapoeiradas), em alguns locais, apresentam-se com grande quantidade de indivíduos jovens de babaçu e inajá (regeneração). Essas áreas são destinadas à criação de gado, especialmente o gado bovino, com finalidade mista (corte e leite).

As principais formações vegetais identificadas foram: Mata de Galeria, Floresta Ombrófila Aberta Submontana, Cerrado Sentido Restrito Ralo e Rupestre, e Cerrado Sentido Restrito Denso e Típico, cobrindo em conjunto de 1.327 hectares, correspondendo a 39\% da área da APA.

A maior parte da área é coberta por floresta Ombrófila. Esta formação florestal conta com árvores espaçadas de alturas aproximadamente uniformes, e com palmeiras (babaçu e inajá). A área com adensamentos de palmeira, onde destacam-se o babaçu e o inajá, marca a transição entre a Floresta Ombrófila Densa Submontana e as fitofisionomias do Cerrado, apresentando-se sob a forma de fragmentos diversos e pequenos, compondo mosaicos. Entre as árvores de grande porte que caracterizam os remanescentes desta Formação encontra-se: jatobá (Hymenaea courbaril), amescla (Protium heptaphyllum), garapa (Apuleia mollaris), itaúba (Mezilaurus itauba), cajú-açú (Anacardium giganteum), inharé (Helicostylis pedunculata), orelha-denegro (Enterolobium schomburgkii), marupá (Simaruba amara), copaíba (Copaifera reticulata) e sapucaia (Lecythis paraensis). 


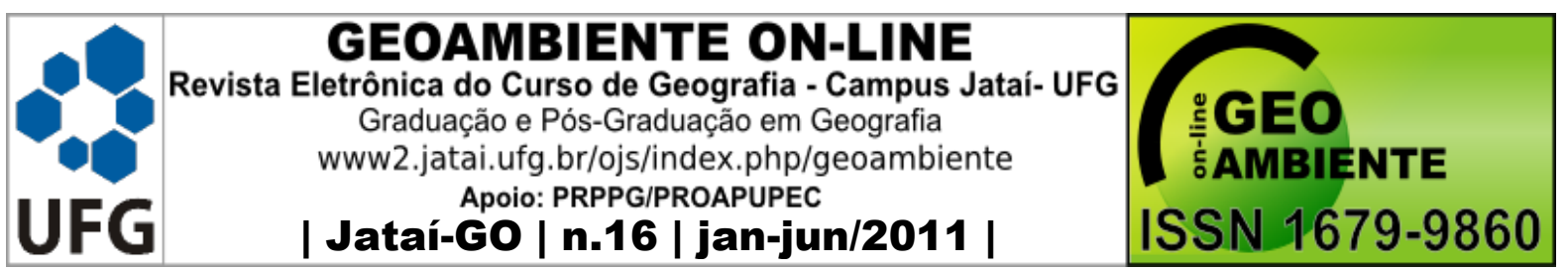

Em alguns pontos, as áreas remanescentes da formação Ombrófila exibem feições de alteração da sua estrutura primária. De maneira similar, ocorrem com as outras fitofisionomias, as quais podem ter sofrido algum distúrbio, como por exemplo, ter sido substituída por pastagem cultivada para cria, recria e engorda de gado bovino. Os remanescentes de vegetação estão dispersos em manchas relativamente isoladas no meio da matriz de ocupação agropecuária (figura 8) e (Tabela 2).

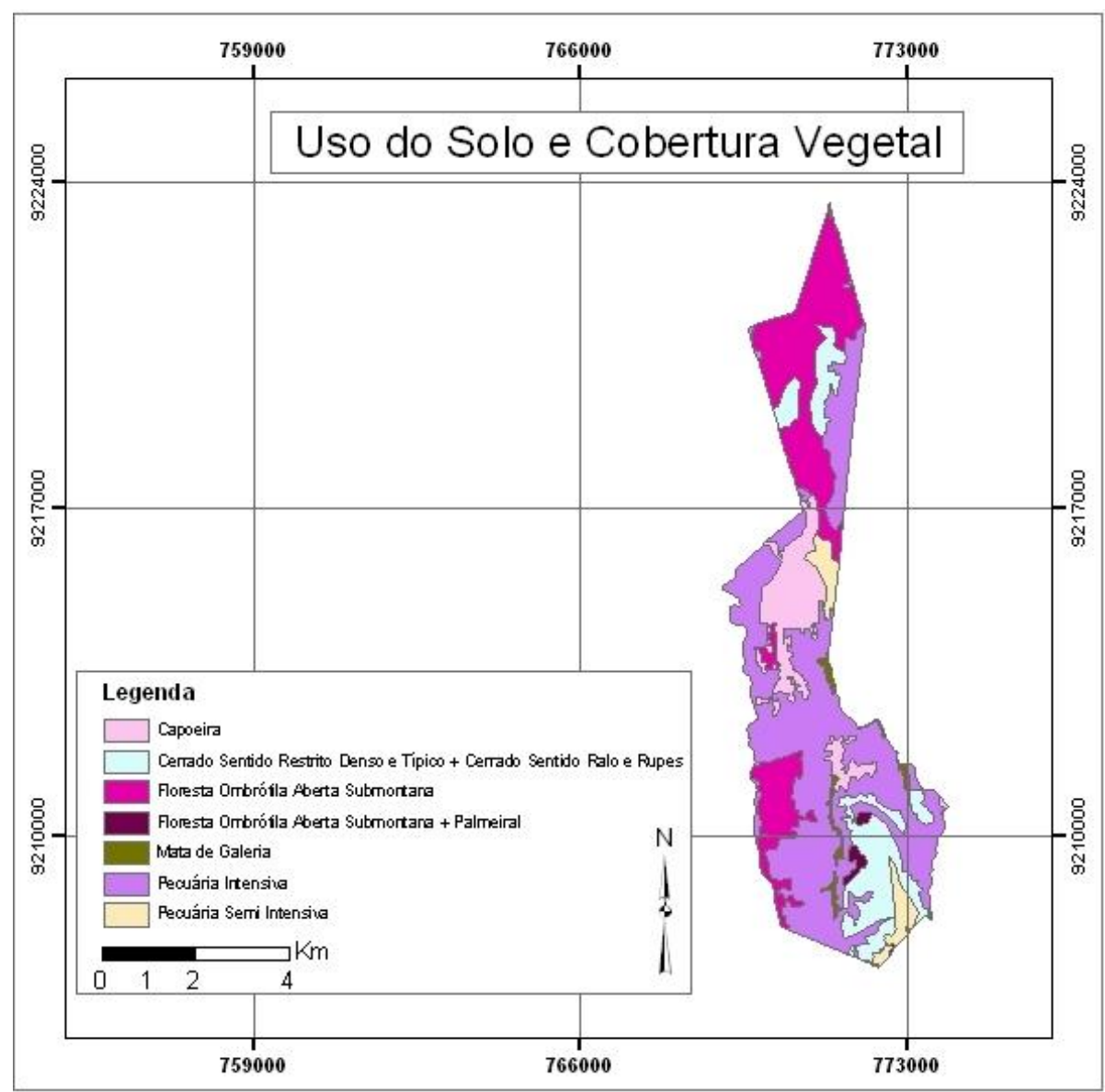

Figura 8- Mapa de Uso do Solo e Cobertura Vegetal APA Pé do Morro.

Fonte: modificado do banco de dados GEO-TOCANTINS/SEPLAN. Elaborado por SOUSA, Benilson P.

Tabela 2 - Quantificação das fitofisionomias mapeadas na APA Pé do Morro. Fonte: Adaptado do banco de dados GEO-TOCANTINS/SEPLAN.

\begin{tabular}{lcc}
\multicolumn{1}{c}{ Fitofisionomias } & Área (ha) & \% \\
\hline Mata de Galeria & 47,5645 & 3,58 \\
Floresta Ombrófila Aberta Submontana & 811,7113 & 61,16 \\
Cerrado Sentido Restrito Denso e Típico + Cerrado Sentido Ralo e & 441,5013 & 33,27 \\
Rupestre & 26,3621 & 1,99 \\
Floresta Ombrófila Aberta Submontana + Palmeiral & $\mathbf{1 . 3 2 7 , 1 3 9 2}$ & $\mathbf{1 0 0}$ \\
\hline \multicolumn{1}{c}{ Total } & &
\end{tabular}




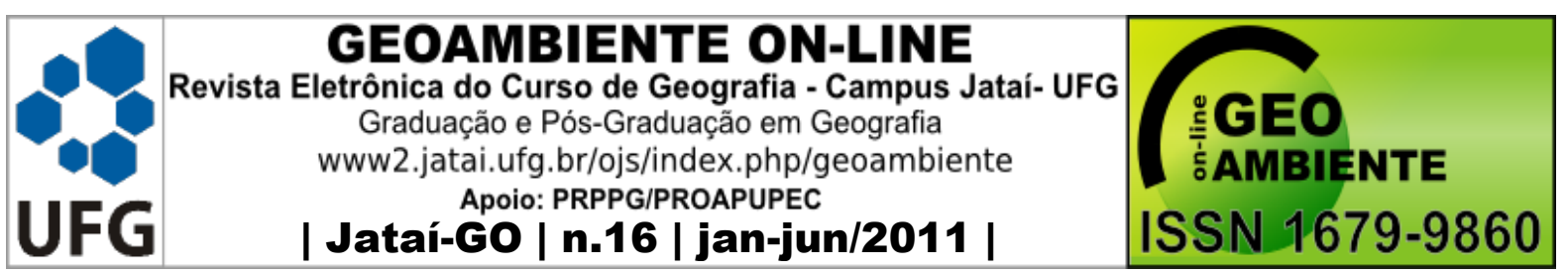

No domínio das rochas e solos existentes, o padrão de drenagem é do tipo dendrítico, sub-retangular, de alta densidade, sendo parcialmente controlado por falhas, fraturas e foliações. O sistema hidrográfico da APA é pertencente a duas Bacias Hidrográficas, a porção centro-norte da unidade é pertencente à Bacia Hidrográfica do Rio Muricizal e os cursos d’água inseridos na parte sul pertencem a Bacia Hidrográfica do Rio Lontra. Ambas, são tributários da margem direita do Rio Araguaia (figura 9).

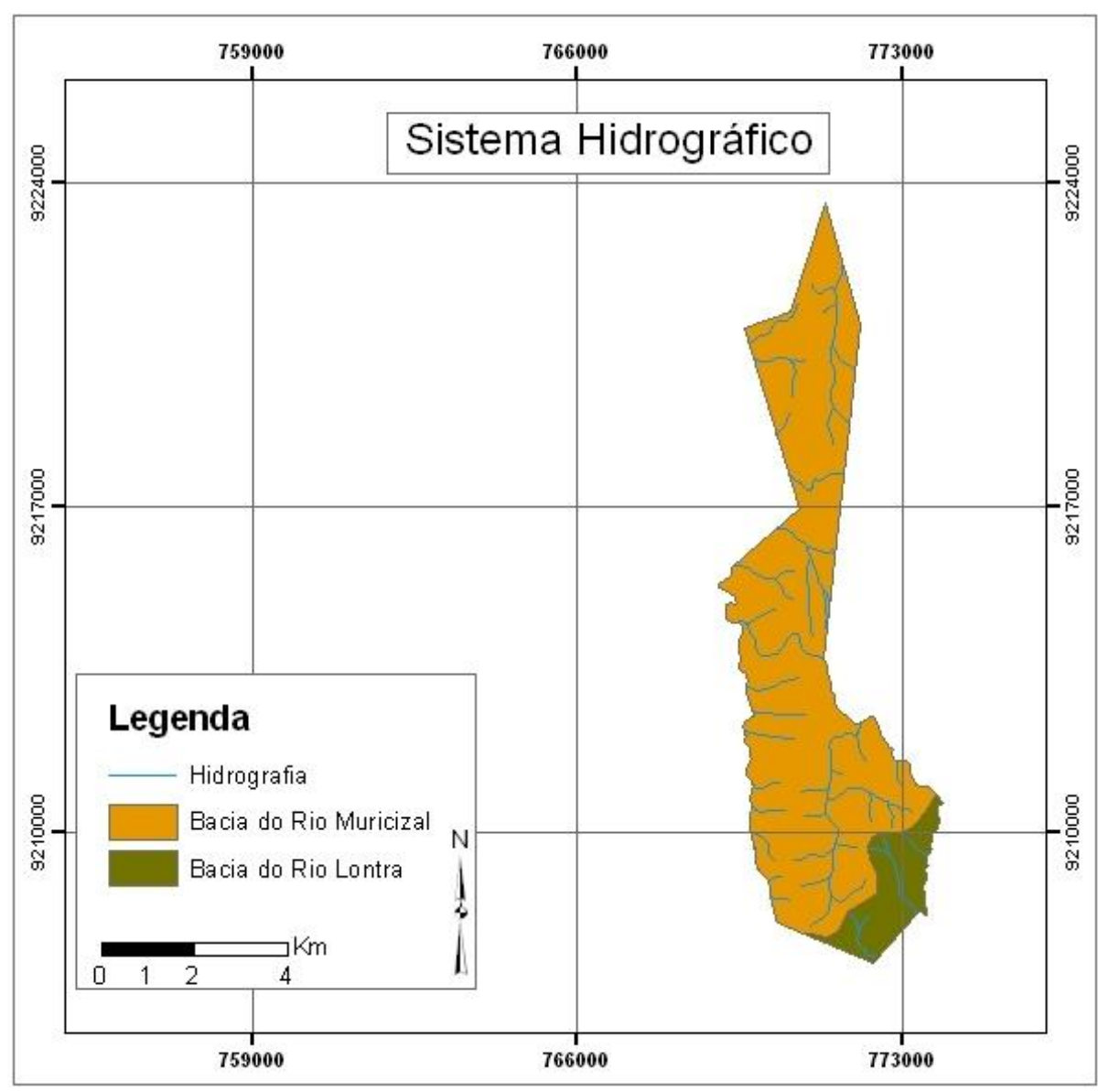

A área está inserida sobre a unidade do Planalto Residual do Araguaia. O relevo desenvolveu-se sobre litologias proterozóicas da Formação Xambioá e apresenta-se dissecado em formas aguçadas. Nesse ponto da unidade sobressaem-se inúmeras cristas ocorrendo de forma alongada em direção aproximada N-S, com cotas altimétricas que variam de 180 a 600 metros (figuras 10 e 11). 


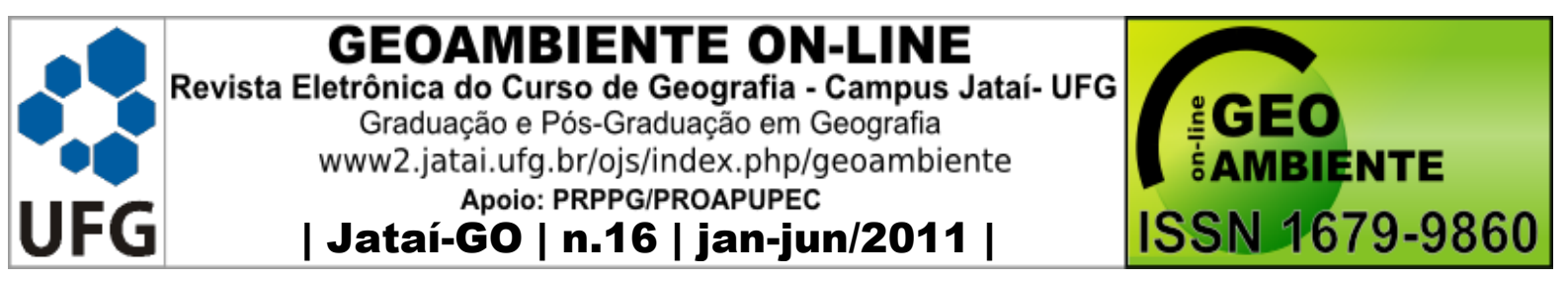

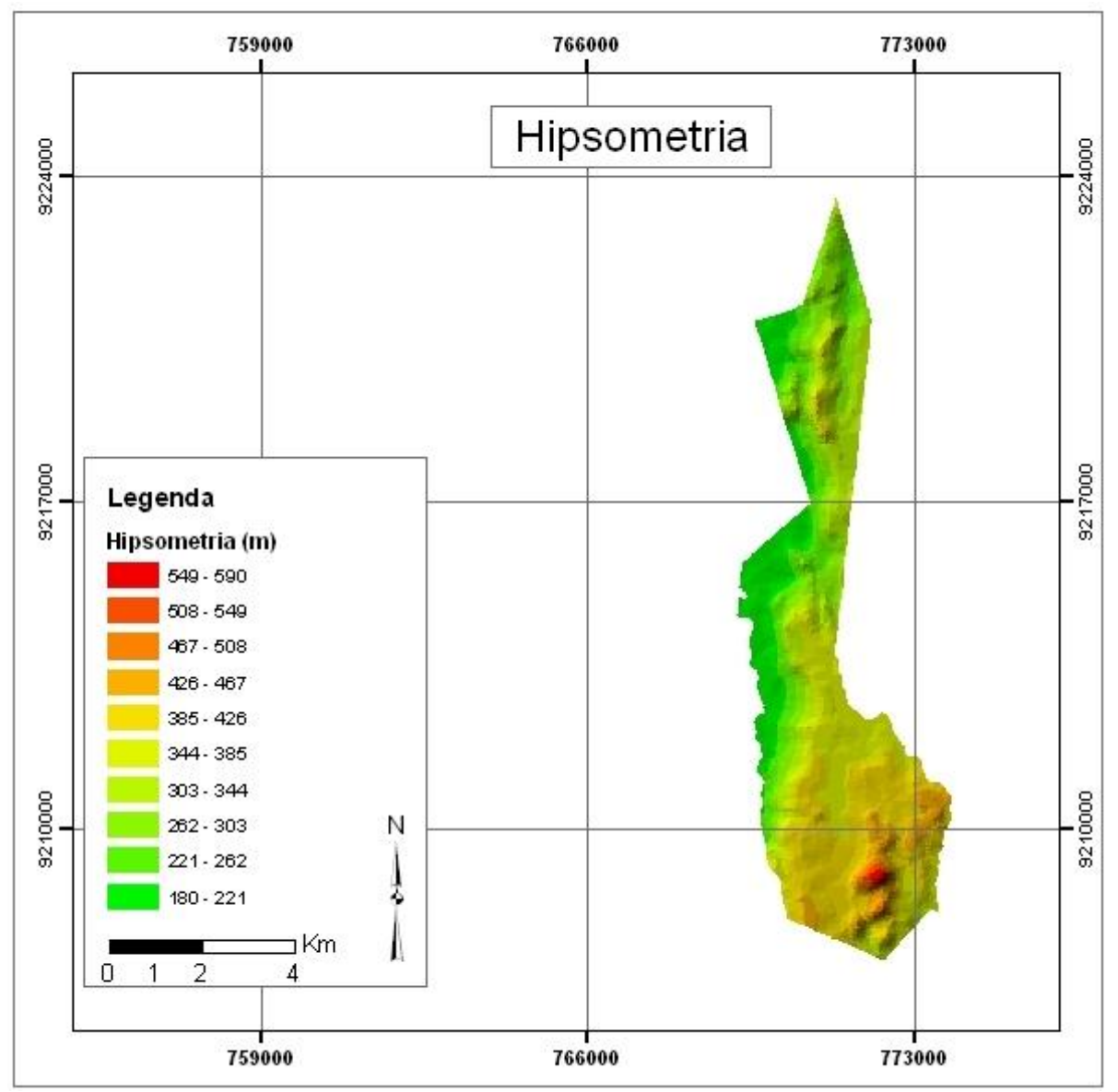

Figura 10 - Mapa Hipsométrico da APA Pé do Morro.

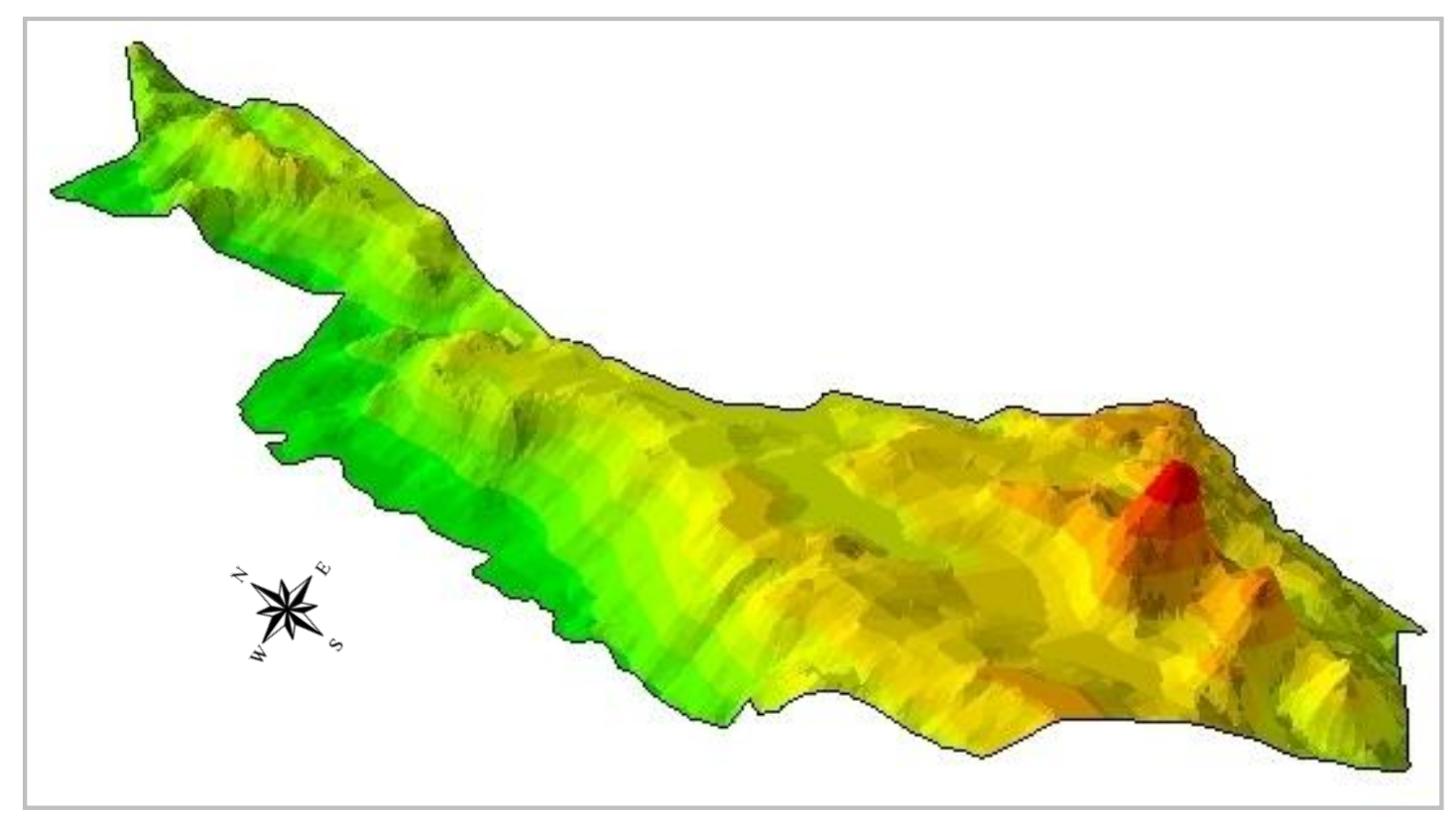

Figura 11 - MDE com dez classes de elevação, desde 180m a 590m de altitude (Sem escala). 


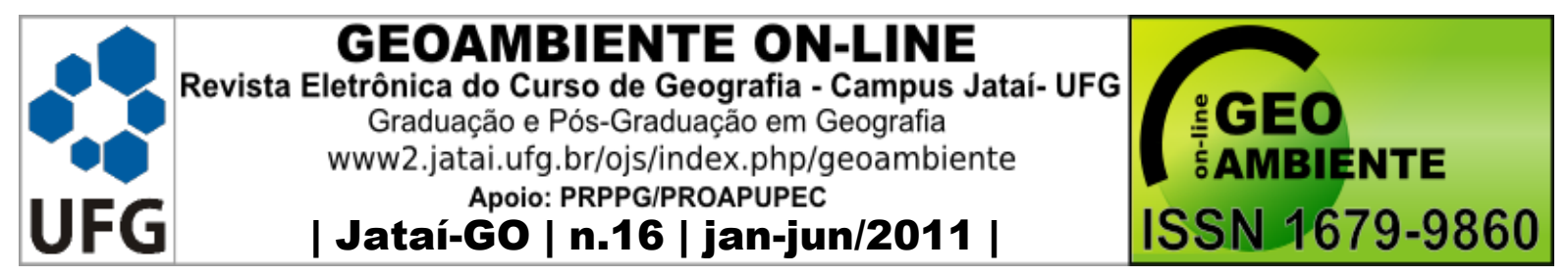

\section{Considerações Finais}

As técnicas de interpretação de imagem de satélite e de geoprocessamento foram empregadas na formação de um banco de dados geográficos sobre a área de estudo, com a produção e manipulação de informações atualizadas sobre os aspectos físicos, biológicos e antrópicos. Estes instrumentos também permitiram uma análise integrada dos elementos que modulam a estrutura e a dinâmica das paisagens local, com a produção de mapas e a caracterização das Unidades Geoambientais.

A análise integrada destas variáveis ambientais teve como resultado a definição dos limites da APA e na identificação de prioridades para a conservação e a recuperação ambiental, em função de sua importância para a manutenção do equilíbrio dos processos ecológicos e de sua fragilidade diante das pressões antrópicos.

A criação da APA Pé do Morro permitirá a conservação de uma porção significativa da biodiversidade local. Terá por definição as finalidades de: disciplinar o processo de ocupação territorial, assegurar a sustentabilidade do uso dos recursos naturais, fomentar o turismo ecológico, fomentar a educação ambiental, melhorar a qualidade de vida das populações residentes através da orientação e disciplina das atividades econômicas locais e preservar a cultura e a tradição da região.

Posterior ao decreto de criação da APA, a mesma necessitará de um detalhamento e complementação destes estudos iniciais, a fim de subsidiar um Plano de Manejo da área. O Plano de Manejo é resultado de uma articulação baseando-se num plano de gestão, diretrizes e normas gerais da APA.

\section{Bibliografias}

ATLAS DO TOCANTINS: Subsídios ao planejamento da gestão territorial. Secretaria do planejamento e do meio ambiente, Diretoria de zoneamento ecológico-econômico - DZE. $4^{\circ}$ ed. Palmas: Seplan, 56p. 2005.

BRASIL, Lei $n^{\circ}$ 9.985, DE 18 DE JULHO DE 2000. Regulamenta o art. 225, § 1o, incisos I, II, III e VII da Constituição Federal, institui o Sistema Nacional de Unidades de Conservação da Natureza (SNUC) e dá outras providências.

BRASIL, Lei $n^{\circ}$ 6.902, DE 27 DE ABRIL DE 1981. Dispõe sobre a criação de Estações Ecológicas, Áreas de Proteção Ambiental e dá outras providências. 


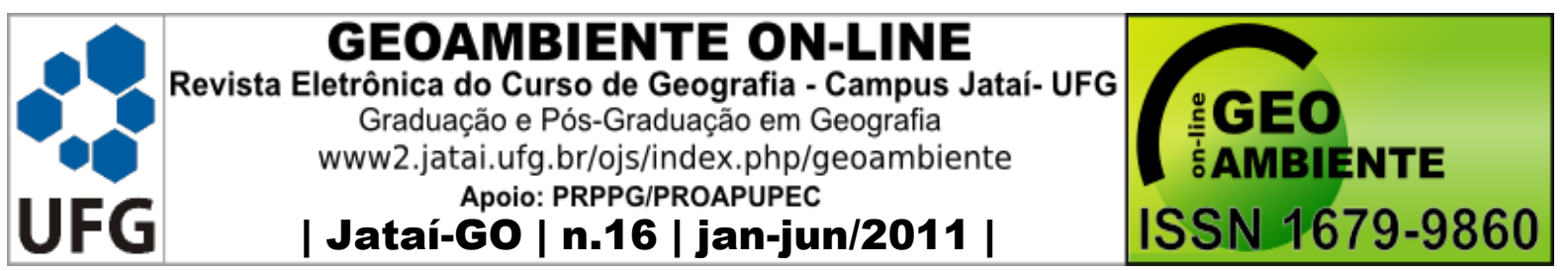

BRITO, R M. Degradação das Matas Ciliares dos Córregos Lages, Zé Mineiro e Gavião no município de Aragominas - TO. Monografia - Araguaína-TO: Campus de Araguaína/UFT, 2006

CABRAL, N.R.A.J. Área de proteção ambiental: planejamento e gestão de paisagens protegidas. São Carlos: Rima, 2002. 154 p.

CBERS, Cena 160/108. SISCOM - Sistema Compartilhado de Informações Ambientais do IBAMA. Disponível em: 〈http://siscom.ibama.gov.br/index.php?page=consulta-por-tabela〉, acessado em: 25 setembro de 2010 .

CONAMA. Resolução 10/88, de 14 de dezembro de 1988. Dispõe sobre a regulamentação das APAs.

CPRM - Serviço Geológico do Brasil. Programa Levantamentos Geológicos Básicos do Brasil - PLGB. Araguaína - Folha SB.22-Z-D, Estados do Tocantins e do Pará. Escala 1:250.000 / Organizado por Vanderlei Antônio de Araújo e Odair Olivatti. - Brasília: CPRM/DIEDIG/DEPAT, 2001.

DIAS, J. R. Unidades Geoambientais da Área de Proteção Ambiental da Serrinha do Alambari - Capelinha, Resende - RJ. Monografia. UFV. Viçosa, 2007.

DRUCK, S.; CARVALHO, M.S.; Câmara, G.; Monteiro, A.V.M. (eds). Análise Espacial de Dados Geográficos. Brasília, EMBRAPA, 2004.

IBGE, Contagem Populacional 2007 - Malha municipal digital do Brasil. Disponível em: <http://www.ibge.gov.br/cidadesat/painel/painel.php?codmun=170130\#> Acesso em: 30 agosto 2010.

LANDSAT, Órbita/ponto 223-65/Anos 2002, 2004 e 2009. SISCOM - Sistema Compartilhado de Informações Ambientais do IBAMA. Disponível em: http://siscom.ibama.gov.br/mapoteca_img/landsat_georef_html/LANDSAT-

GEORREFERENCIADA.html>, acessado em: 25 agosto de 2010.

MIRANDA, E. E. de; (Coord.). Brasil em Relevo. Campinas: Embrapa Monitoramento por Satélite, 2005. Disponível em: <http://www.relevobr.cnpm.embrapa.br>. Acesso em: 20 setembro 2010.

PERINOTTO, A. R. Geoturismo nas Cuestas Basálticas da alta Bacia do Rio Corumbataí (município de Analândia/SP). Geoturismo. Revista Global Tourism. São Paulo-SP. Vol. 3, No 2. 2007. 


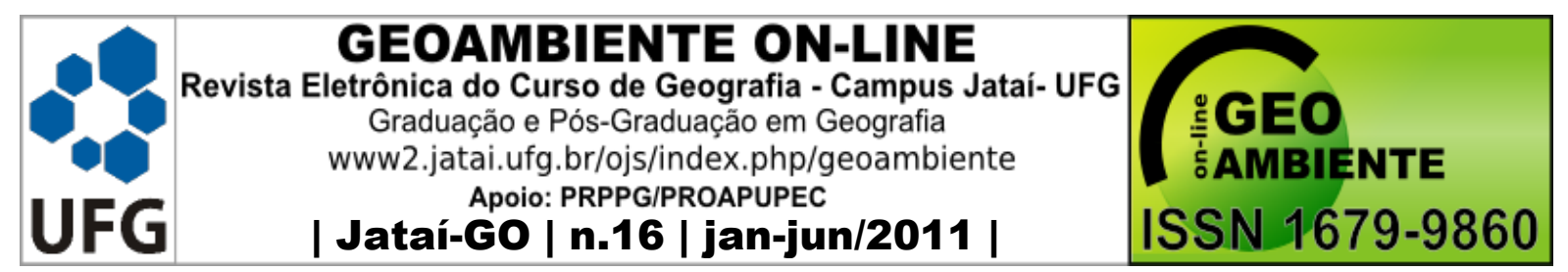

TAMANINI, M.S.A. Diagnóstico físico-ambiental para a determinação da fragilidade potencial e emergente da bacia do baixo curso do Rio Passaúna em Araucária - Paraná. 2008. 118 f. Dissertação (Mestrado)-Programa de Pós-graduação em Geografia, Universidade Federal do Paraná. Curitiba-PR, 2008.

TOCANTINS - NATURATINS. Unidades de Conservação do estado do Tocantins. Disponível em: <http://areasprotegidas.to.gov.br/ >, acessado em: 03 de agosto de 2010.

Secretaria do Planejamento e Meio Ambiente (SEPLAN). Diretoria de Zoneamento Ecológico-Econômico (DZE). Projeto de Gestão Ambiental Integrada da Região do Bico do Papagaio. Zoneamento Ecológico-Econômico. Base de Dados Geográficos do Norte do Tocantins. Palmas, Seplan/DZE, 2005. CDROM.

PÉREZ, A. M. F. Modelos Digitales del Terreno - Introducción y aplicaciones en las ciencias ambientales. Tese Doctoramento en Ciências, Universidad de Oviedo, 1992. Espana. Pentalfa Ediciones

ZEE-BICO. Projeto de Gestão Ambiental Integrada da Região do Bico do Papagaio. Zoneamento Ecológico-Economico. Secretaria do Planejamento e Meio Ambiente (Seplan). Diretoria de Zoneamento Ecológico-Economico (DZE). Araguaína: Geomorfologia da Folha SB.22-Z-D. estado do Tocantins. Escala 1:250.000. org. por Ricardo Ribeiro Dias e Rodrigo Sabino Teixeira Borges. 2.ed. Palmas, Seplan/DZE, 2004.

Araguaína: Solos da Folha SB.22-Z-D. estado do Tocantins. Escala 1:250.000. org. por Ricardo Ribeiro Dias e Rodrigo Sabino Teixeira Borges. 2.ed. Palmas, Seplan/DZE, 2004. ZEE-BICO. Projeto de Gestão Ambiental Integrada da Região do Bico do Papagaio. Zoneamento Ecológico-Economico. Secretaria do Planejamento e Meio Ambiente (Seplan). Diretoria de Zoneamento Ecológico-Economico (DZE). Inventário Florestal e Levantamento Florístico do Norte do Estado do Tocantins. Estado do Tocantins. Escala 1:250.000. org. por José Roberto Ribeiro Forzani. 2.ed. Palmas, Seplan/DZE, 2005. 